\title{
Marx on Social Reproduction
}

\author{
Paul Cammack \\ Global Development Institute, University of Manchester, Manchester, UK \\ pcammackor@gmail.com
}

\begin{abstract}
Marx is generally reckoned to have had too little to say about what has come to be defined as 'social reproduction', largely as a consequence of too narrow a focus on industrial production, and a relative disregard for issues of gender. This paper argues in contrast that the approach he developed with Engels and in Capital, Volume 1, provides a powerful framework for its analysis. After an introductory discussion of recent literature on social reproduction the second section sets out Marx's approach to the 'production of life, both of one's own in labour and of fresh life in procreation'. The third addresses his account of reproduction in Capital, Volume 1, Chapter 23. The fourth and fifth compare the relationship of the family to industry and exchange as depicted in Capital and in the present day respectively. The conclusion suggests some implications for theories of social reproduction.
\end{abstract}

\section{Keywords}

Marxism - procreation - social reproduction

\section{Introduction}

The recent re-publication of Margaret Benston's classic 1969 article, 'The Political Economy of Women's Liberation', in a special fiftieth-anniversary issue of Monthly Review honouring its original publication, ${ }^{1}$ along with special issues of Historical Materialism, Radical Philosophy and Viewpoint Magazine on

1 Monthly Review 2019. 
social reproduction, ${ }^{2}$ following upon the earlier re-publication of Lise Vogel's Marxism and the Oppression of Women (1983), ${ }^{3}$ constitute evidence of a major effort to renew Marxist-Feminism by returning to 'the activities associated with the maintenance and reproduction of peoples' lives on a daily and intergenerational basis. ${ }^{4}$

Benston's starting point was 'that women as a group do indeed have a definite relation to the means of production and that this is different from that of men'. ${ }^{5}$ Whether or not they participated in wage labour, it was their exclusive responsibility for 'the production of simple use-values in those activities associated with the home and family' that defined them. ${ }^{6}$ At the same time, though, the household was a preindustrial production unit in which production was 'small-scale and reduplicative', giving rise to a great number of small multi-purpose kin-based units, 'each complete and just like all the others'; crucially, she noted, the 'rationalization of production effected by a transition to large-scale production has not taken place in this area.' ${ }^{7}$ Wally Seccombe subsequently identified 'four basic household types, each with a distinctive fertility regime', in the period of demographic transition in Western Europe: peasant, proto-industrial, early proletarian and mature proletarian, with only the latter characterised by a 'primary male breadwinner'. ${ }^{8}$ And Antonella Picchio, in her classic account of the implications of access to the means of subsistence mediated by wages, proposed that whereas 'the independent household produced for the reproduction of its members, the capitalist economy uses the reproduction of the labouring population for the accumulation of capital'; it was only when labour became waged labour that 'the work of reproduction became unwaged housework. ${ }^{9}$ As I have argued at greater length elsewhere, in her account the mediating role of wages is the only fixed feature of the interconnectedness of production and social reproduction, with everything else subject to change..$^{10}$ Taken together, these pioneering contributions identify three key features of the interdependence of domestic and industrial production that shape the circumstances in which women take sole or predominant

\footnotetext{
$2 \quad$ Historical Materialism 2016; Radical Philosophy 2019; Viewpoint Magazine 2015; see also Bhattacharya (ed.) 2017. 
responsibility for the former - the pre-capitalist character of domestic production, the differentiation of households and their survival strategies by class, and the mediating role of the wage. At the same time, they reflect the fact that the extent to which household production relies upon the purchase of commodities and services in the market, the division of labour by gender in the household, and the allocation of women's labour between the household and waged work all vary from place to place and time to time. Beyond this, private households are not the only site in which labour-power is prepared, maintained and renewed.

Approaches such as these that drew directly on Marx quickly came up against the fact that he is generally reckoned, even by writers who place themselves squarely in the Marxist tradition, to have had too narrow a focus on industrial as opposed to domestic production, and a relative disregard for gender relations and, by extension, the oppression of women. So it is widely argued that his work needs to be developed, supplemented or corrected if these issues are to be adequately analysed within an historical-materialist framework. The distinction made by Barbara Laslett and Johanna Brenner between Marx's view of 'societal reproduction' and a concept that would include 'not only the organization of production but the organization of social reproduction, and the perpetuation of gender as well as class relations' typifies this argument, ${ }^{11}$ as does the widely shared view that more account needs to be taken of the facts that capitalism depends upon a non-capitalist sector, to which the family or household is central, for the renewal of labour-power from day to day and generation to generation, ${ }^{12}$ and that '[i]f children are to be born, it is women who will carry and deliver them.13 In sum, the charge is that Marx ironically 'leaves undeveloped or undertheorized the production and reproduction of labour power.'14

This essay argues, against this consensus, that Marx, in part in early association with Engels but primarily in the Grundrisse and in Capital, Volume 1, provides a powerful framework for the analysis of 'social reproduction', of unmatched relevance today. It takes as its starting point the broad understanding of production expressed in the German Ideology, and the insistence that "the "history of humanity" must always be studied and treated in relation to the history of industry and exchange.'. ${ }^{15}$ It then explores the suggestion that

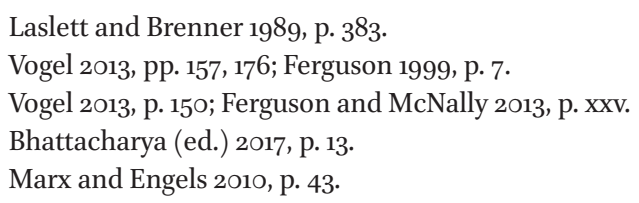


for capital '[e]very limit appears as a barrier to be overcome', ${ }^{16}$ with reference to two key processes identified as central to the transformation of production through competition - the breaking down of processes of production into their smallest constituent elements, regardless of the capacity of the human hand, and the conscious and planned application of natural science in pursuit of greater productivity. It then examines what Marx had to say about 'societal reproduction' directly. In substantive terms, the argument is that both Marx and Engels were assiduous in seeking out evidence of the impact of the advent of large-scale industry on gender relations within the household, and relations between the household and the broader society, but that given the limited development of domestic production in their time, and the absence of any advanced division of labour or application of science to procreation, there was not much in concrete terms for them to say on the transformation of these aspects of production by capital. But subsequent scientific and technological advances have transformed both domestic production and the production of life itself in a manner that confirms the validity of the analysis that Marx and Engels developed.

\section{The Production of Life}

From the very start, in the earliest outlines of their historical-materialist approach, Marx and Engels insisted upon its comprehensive scope. In the German Ideology, they suggested that what men and women are 'coincides with their production, both with what they produce and with how they produce.'17 Describing the family as 'to begin with ... the only social relation', they added that it 'becomes later, when increased needs create new social relations and the increased population new needs, a subordinate one ..., and must then be treated and analysed according to the existing empirical data, not according to "the concept of the family", as is the custom in Germany'. ${ }^{18}$ This leads directly to the statement that ' $[t]$ he production of life, both of one's own in labour and of fresh life in procreation, now appears as a twofold relation: on the one hand as a natural, on the other as a social relation - social in the sense that it denotes the cooperation of several individuals, no matter under what conditions, in what manner and to what end. ${ }^{19}$ Biological reproduction, then, is just as much

$16 \quad$ Marx 1973, p. 408.

17 Marx and Engels 2010, pp. 31-2.

18 Marx and Engels 2010, p. 43.

19 Ibid. 
a social relation as is the production of one's own life in labour. Later in the same text, the sense in which both can also be considered 'natural' is made clear. Immediately following the statement that with the industrial revolution competition 'produced world history for the first time, insofar as it made all civilised nations and every individual member of them dependent for the satisfaction of their wants on the whole world, thus destroying the former natural exclusiveness of separate nations', Marx and Engels say that it 'made natural science subservient to capital and took from the division of labour the last semblance of its natural character. It altogether destroyed the natural character, as far as this is possible with regard to labour, and resolved all natural relations into money relations. ${ }^{20}$

So Marx and Engels did not see biological reproduction as a natural as opposed to a social relation. The contrast was rather between a 'natural' process, and one that is resolved into a 'money relation', as far as is possible with regard to labour, this being a point to which I shall return. Hence the earlier insistence that "the "history of humanity" must always be studied and treated in relation to the history of industry and exchange.'. ${ }^{21}$

The argument is developed further in the drafts preparatory to Capital known as the Grundrisse, and in Capital itself. In the Grundrisse Marx suggests that in bourgeois society, where capital is dominant, it assigns rank and influence to other modes of production, which at the same time appear to it as barriers to overcome: it seeks 'to subjugate every moment of production itself to exchange and to suspend the production of direct use values not entering into exchange, i.e. precisely to posit production based on capital in place of earlier modes of production, which appear primitive from its standpoint'.22 In Capital, he presents the whole process as pressed forward by competition between capitalists who seek to drive the cost of production down, resulting in continual scientific and technological revolutions, and an uninterrupted process of division of labour, proceeding without regard for the capacity of the human hand, and eventually reflected in a 'general law of social production', according to which 'totally developed' individuals are under pressure to be 'absolutely available' for the different kinds of labour required of them. ${ }^{23}$ To all of this, the advance of science and its technical applications was central: Marx says first of large-scale industry that its principle, 'which is to view each process of production in and for itself, and to resolve it into its constituent elements without

\footnotetext{
$20 \quad$ Marx and Engels 2010, p. 73.

21 Marx and Engels 2010, p. 43.

22 Marx 1973, pp. 106-7, 408.

23 Marx 1976, p. 618.
} 
looking first at the ability of the human hand to perform the new processes, brought into existence the whole of the modern science of technology'. And immediately following, '[t]he varied, apparently unconnected and petrified forms of the social production process were now dissolved into conscious and planned applications of natural science, divided up systematically in accordance with the particular useful effect aimed at in each case. ${ }^{24}$

Given their historical-materialist premises, then, Marx and Engels saw 'specific scientific disciplines as developing in response to problems arising in the sphere of production'. ${ }^{25}$ Rosenberg's seminal essay on this issue brings out the significance of the three stages of production identified by Marx: handicraft, in which each worker produces a complete article; manufacture, where the division of labour means that each individual worker carries out a single operation in an otherwise unchanged production process, making possible more efficient production on a larger scale; and 'modern industry', or machino-facture, centred on machinery driven by power, in which the production process itself is transformed. Rosenberg cites at length the passage from Capital in which Marx describes manufacture as coinciding completely with the decomposition of a handicraft into its different partial operations, so that each operation "has to be done by hand, retains the character of a handicraft, and is therefore dependent on the strength, skill, quickness, and sureness with which the individual worker manipulates his tools', argues that this 'technically narrow' basis 'excludes a really scientific division of the production process into its component parts', and notes that as a result 'every worker becomes exclusively assigned to a partial function and that his labour-power becomes transformed into the life-long organ of this partial function: ${ }^{26}$ In contrast, the distinctive technological feature of modern industry is that 'for the first time, the design of the productive process is carried out on a basis where the characteristics of the worker and his physical endowment are no longer central to the organization and arrangement of capital. Rather, capital is being designed in accordance with a completely different logic, a logic which explicitly incorporates principles of science and engineering., ${ }^{27}$ So, Marx concludes:

\footnotetext{
24 Marx 1976, pp. 616-17.

25 Rosenberg 1974, p. 715.

26 Marx 1976, pp. 457-8, cited p. 719, footnote 13. Note that Rosenberg used the 1906 version of Capital, published in Chicago by Charles H. Kerr and Company, and has slightly different wording. I have substituted the equivalent text from the 1976 edition used throughout this paper both here, and in the paragraph cited below, as I refer back to these passages later.

27 Rosenberg 1974, pp. 720-1.
} 
In manufacture, it is the workers who, either singly or in groups, must carry on each particular process with their manual implements. The worker has been appropriated by the process; but the process had previously to be adapted to the worker. This subjective principle of the division of labour no longer exists in production by machinery. Here the total process is examined objectively, viewed in and for itself, and analysed into its constitutive phases. The problem of how to execute each particular process, and to bind the different partial processes together into a whole, is solved by the aid of machines, chemistry, etc. ${ }^{28}$

This is where the application of the analytical framework of Capital to the activities associated with the maintenance and reproduction of peoples' lives on a daily and intergenerational basis must begin. Over history and still today, domestic labour carried out in the family-based household and predominantly carried out by women has been central to the process. But to begin with this empirical observation is directly contrary to a fundamental precept of the 'method of political economy' as set out in the Grundrisse, where Marx, taking as his example 'the population, which is the foundation and the subject of the entire social act of production', declines to start from 'the real and concrete', on the grounds that the concrete is concrete 'because it is the concentration of many determinations, hence unity of the diverse'. Hence, 'if I were to begin with the population, this would be a chaotic concept of the whole, and I would then, by means of further determination, move analytically towards ever more simple concepts, from the imagined concrete towards ever thinner abstractions until I had arrived at the simplest determinations. From there the journey would have to be retraced until I had finally arrived at the population again but this time not as the chaotic conception of a whole, but as a rich totality of many determinations and relations. ${ }^{29}$

In this perspective, the defining feature of the household in relation to the history of industry and exchange, as Benston noted, is that even when the application of advances in science allows the increasing use of new tools or machinery, production remains 'primitive' from the standpoint of capital. To be precise, they are introduced into units that are 'small-scale and reduplicative', 30 and in which there are limited opportunities for a division of labour in which different steps in a process might advantageously be carried out by different individuals using different tools. Following Marx, the characteristics of the

28 Marx 1976, pp. 501-2, cited p. 721.

29 Marx 1973, pp. 100-1.

$30 \quad$ Benston 2019, p. 5 . 
worker and her physical endowment are central to the organisation and arrangement of production; each operation 'has to be done by hand, retains the character of a handicraft, and is therefore dependent on the strength, skill, quickness, and sureness with which the individual worker manipulates [her] tools'; there is a tendency for every worker to become exclusively assigned to a partial function, with her labour-power transformed into 'the life-long organ of this partial function', and the 'technically narrow' basis of production 'excludes a really scientific division of the production process into its component parts'. ${ }^{31}$

The degree of skill required, and therefore the tendency for a particular 'partial function' to be exclusively assigned to one individual, varies from task to task. It is one thing to peel a potato or boil an egg, another to make a wellseasoned curry; one thing to wash the dishes after dinner, another to iron a shirt or put up a shelf; and so on. But the important principle is that the extent to which domestic production can be transformed through the application of science is limited. It retains the character of handicraft, and lacks even the potential for an advanced division of labour that is characteristic of manufacture, let alone the transformation possible in large-scale industry.

Within these limits, the extent to which production of use-values for the reproduction of labour-power takes place within the household rather than outside it varies across both space and time. First, in a two-class society in which the majority are dependent upon a wage, the rich will employ the poor to carry out domestic tasks; as incomes rise, the wider use of gardeners, windowcleaners and other trades related to domestic maintenance will increase; and as the possibilities for international mobility increase, such services will be available from a global workforce. Second, households may take advantage of advances in industrial production to purchase goods and services - village ovens and mills, commercial laundries, canned food, dried pasta, refrigerators, washing machines, 'biological' washing powder - that save labour, improve performance, or allow for economy through the storage of food. Third, and again dependent on the state of scientific and technological development, collective provision through the state may render some household tasks simpler or redundant, as with refuse-collection, or the provision of clean water on tap. Beyond the characteristics of production within the household, then, the outsourcing of domestic tasks may take place through the employment of outside labour, the purchase of goods or services, or collective provision by the state.

Similar considerations apply to the production of fresh life in procreation. Until recently, only one method of production was available; the division of labour involved was simple; the characteristics of the producers and their

$31 \quad$ Marx 1976, pp. 457-8. 
physical endowments were central; and there was little scope (limited perhaps to knowledge of cycles of fertility) for the application of science. In Marx's day and long after, there was no scope for breaking down the process of production into its constituent parts (conception, gestation and birth) susceptible to a division of labour, and out-sourcing was only possible for the initial male contribution of sperm. Scientific advances did in his time lead to improvement in methods for guarding against conception: rubber condoms became available in the 185os, following Goodyear's introduction of vulcanisation. But even more than the production of use-values within the household, human reproduction remained quintessentially 'primitive from the point of view of capital'.

The remark highlighted above, that the transformation of 'natural' into 'money' relations, or the seizure and transformation of 'primitive' forms of production by capital, will take place 'as far as is possible with regard to labour' is crucial here. For Marx and Engels in their own lifetimes, it was not possible. The production of fresh life in procreation was and remained an exclusively natural social process in their terms, featuring a 'petrified' means of production outside the sphere of capital, and a fixed gendered division of labour. Sticking to the empirical observation of 'real individuals, their activity and the material conditions of their life ... verified in a purely empirical way', ${ }^{32}$ as their method required, they did not speculate about possible alternatives to the method of procreation through physical heterosexual coupling and gestation of the infant to term in the womb following successful conception that might one day be made possible by as-yet unknown science. However, their analytical framework allowed for the possibility and even presumed in principle that in this area of production as in others capital could at some point break down the process into its constituent parts, and resolve the production of fresh life through procreation into a series of monetary relations. Indeed, late in his life Engels noted the beginnings of cell and protein biology, but recognised that the state of knowledge was insufficient for firm conclusions to be reached as to its import. ${ }^{33}$ The production of life, in all its aspects, had still to be approached, in principle, in relation to an emerging bourgeois mode of production, with its incessant division of labour, constant technological revolution, universal competition, and the subordination of natural science to capital. As Martha Gimenez noted, in a path-breaking analysis first published in 1991, and recently republished in amended form, the eventual development of reproductive technologies fragmented biological processes and opened them to manipulation, 'thus bringing about unforeseen changes in the social relations within which

$32 \quad$ Marx and Engels 2010, p. 31.

33 Rosenberg 1974, p. 726, especially footnote 28. 
children are brought into the world. ${ }^{34}$ By splitting off intergenerational social reproduction from creation, she argued, it gave rise to 'the capitalist mode of procreation', making it 'possible for individuals or couples to purchase the different elements of the reproductive process to "build", eventually, a baby for themselves. ${ }^{35}$ Procreation turned out to be no more immune to capture by capital - breaking the process of production down into its constituent parts through conscious and planned applications of natural science, and subjugating every moment of production to exchange - than anything else. And this in turn spoke directly to the history of the family in terms of industry and exchange: while capitalist development at one point selected the nuclear-family form 'as the most "functional" for daily and intergenerational reproduction', it 'constantly undermines it through changes in the productive forces in the realms of production and reproduction'. ${ }^{36}$

\section{3}

\section{Social Reproduction}

With this in mind, we can turn to Capital, Volume 1, Chapter 23, in which Marx addresses social processes of reproduction directly. It is here that he insists on the coincidence of production and reproduction:

Whatever the social form of the production process, it has to be continuous, it must periodically repeat the same phases. A society can no more cease to produce than it can cease to consume. When viewed, therefore, as a connected whole, and in the constant flux of its incessant renewal, every social process of production is at the same time, a process of reproduction. The conditions of production are at the same time the conditions of reproduction. ${ }^{37}$

If Marx does not give separate consideration to social reproduction, then, it is because the 'social process of reproduction' is nothing other than the net result of the social process of production. And as he goes on to say, for capital the priority was not the production of human beings in general, or of future generations, but the production of workers, or the maintenance of the 'capital relation'. As Gimenez observed, in an essay first published in 1990, 'people, in themselves,

\footnotetext{
34 Gimenez 2019, p. 188.

35 Gimenez 2019, pp. 189-9o.

$36 \quad$ Gimenez 2019, p. 196.

$37 \quad$ Marx 1976, p. 711.
} 
without marketable skills, have no value under capitalist conditions. ${ }^{38}$ So Marx began his analysis of 'simple reproduction' with the issue of the production of the worker as a 'dispossessed producer of surplus value', ${ }^{39}$ tracing the process through which workers produce both their own future wages, a surplus for the capitalist, and the system that disciplines and enchains them. The portion of 'variable capital' (money advanced to purchase the inputs to production, labour included) that goes to workers, he argued, constitutes 'the fund for providing the means of subsistence, or the labour fund', while the workers' own product 'constantly moves away from [them] in the form of capital'. ${ }^{40}$ In this way the capitalist 'produces the worker as a wage-labourer': 'This incessant reproduction, the perpetuation of the worker, is the absolutely necessary condition for capitalist production. ${ }^{41}$ This point is crucial - it is the perpetuation of the worker that is the absolutely necessary condition for capitalist production, and it is in this light that the production and maintenance of human beings is to be addressed. Only after having addressed the production and reproduction of the human being as a worker, obliged to sell their capacity to work to the capitalist, does Marx go on to consider the process of production of life itself under capitalism:

The capital given in return for labour-power is converted into means of subsistence which have to be consumed to reproduce the muscles, nerves, bones and brains of existing workers, and to bring new workers into existence. Within the limits of what is absolutely necessary, therefore, the individual consumption of the working class is the reconversion of the means of subsistence given by capital in return for labour-power into fresh labour-power which capital is then again able to exploit. It is the production and reproduction of the capitalist's most indispensable means of production: the worker... The maintenance and reproduction of the working class remains a necessary condition for the reproduction of capital. ${ }^{42}$

A discussion earlier in Capital, where Marx notes that, all the same, the individual capitalist takes no account of the general conditions required for the maintenance and reproduction of the working class, is directly relevant here.

\footnotetext{
$38 \quad$ Gimenez 2019, p. 247.

39 Bonefeld 2014, p. 87.

$40 \quad$ Marx 1976, p. 713 .

41 Marx 1976, p. 716; emphasis mine.

42 Marx 1976, pp. 717-18; emphasis mine.
} 
There Marx identified the paradox that on the one hand workers must be insecure, and unable to survive without direct or indirect access to wages, while on the other capital must be assured of a supply of labour. This reflects a fundamental contradiction in relation to the reproduction of the worker, expressed by Marx in the statement that 'Capital asks no questions about the length of life of labour-power': 'By extending the working day ... capitalist production, which is essentially the production of surplus-value, the absorption of surplus labour, not only produces a deterioration of human labour-power by robbing it of its normal moral and physical conditions of development and activity, but also produces the premature exhaustion and death of this labour-power itself. It extends the worker's production-time within a given period by shortening his life' ${ }^{43}$

This phenomenon, recently identified as particularly relevant in the context of neoliberally induced austerity, ${ }^{44}$ is in fact inherent in the bourgeois mode of production. Capital, left to itself, tends to destroy life, not to produce and reproduce it, as it reproduces itself only through the activities of individual capitalists, who disregard the needs and limitations of the human body. Marx sets out clearly the contradiction this involves, and the presumptive inference that capital should protect the capacity of workers to reproduce themselves from day to day:

the value of labour-power includes the value of the commodities necessary for the reproduction of the worker, for continuing the existence of the working class. If then the unnatural extension of the working day, which capital necessarily strives for in its unmeasured drive for selfvalorization, shortens the life of the individual labourer, and therefore the duration of his labour-power, the forces used up have to be replaced more rapidly, and it will be more expensive to reproduce labour-power, just as in the case of a machine, where the part of its value that has to be reproduced daily grows greater the more rapidly the machine is worn out. It would seem therefore that the interest of capital itself points in the direction of a normal working day. ${ }^{45}$

However, just as slave-owners can rationally work their slaves to death, as 'when [their] place can at once be supplied from foreign preserves, the duration of [their] life becomes a matter of less moment than [their] productiveness while

43 Marx 1976, pp. 376-7.

44 Rai, Hoskyns and Thomas 2014.

45 Marx 1976, p. 377; emphasis mine. 
it lasts', 'experience generally shows to the capitalist ... a constant excess of population', with the result that:

Capital ... allows its actual movement to be determined as much and as little by the sight of the coming degradation and final depopulation of the human race, as by the probable fall of the earth into the sun. In every stock-jobbing swindle everyone knows that some time or other the crash must come, but everyone hopes that it may fall on the head of his neighbour, after he himself has caught the shower of gold and placed it in secure hands. Après moi le déluge! is the watchword of every capitalist and of every capitalist nation. Capital therefore takes no account of the health and length of life of the labourer, unless society forces it to do so. ${ }^{46}$

This is the logic of capital. It is not a matter of caprice, but a consequence of the intrinsic character of capitalist competition: 'Under free competition, the immanent laws of capitalist production confront the individual capitalist as a coercive force external to him'. ${ }^{47}$ This destructive tendency in capital may be offset by legislation, as in the successive Factory Acts from 1833 onwards, or by workers' successful resistance to the demands of the capitalist, but the underlying contradiction remains.

Even if labour is in chronically short supply, the suggestion is, capitalists, under the compulsion of the immanent laws of capitalist production, will still work their workers to death. But as noted above, experience at the time generally showed the capitalist 'a constant excess of population': Marx supports the point with E.G. Wakefield's chilling remark that the over-worked 'die off with strange rapidity; but the places of those who perish are instantly filled, and a frequent change of persons makes no alteration in the scene. ${ }^{48}$ So while there was a latent contradiction between the propensity of 'capital' - in the form of existing individual capitalists - to take no account of the health and length of life of the labourer, and the absolute need for a proletariat as the source of surplus-value, it was not a concern in practical terms, because the supply of fresh labour was to all appearances infinite.

The relevance of these considerations to 'social reproduction' is clear. Just as capital 'asks no questions about the length of life of labour-power', it asks no questions about its renewal from generation to generation. And just as there appeared at the time to be no shortage of workers from day to day, there

$46 \quad$ Marx 1976, pp. 377, 380-1.

$47 \quad$ Marx 1976, p. 381.

48 Marx 1976, p. 380, footnote 79 . 
appeared to be no danger of any shortage in the future. On the contrary, it was the general view among the political economists of the day - with Malthus and John Stuart Mill among the most prominent - that there was an endemic threat of excessive population growth, as widely discussed in a literature with which Marx and Engels show thorough familiarity in their earliest writings: Engels paraphrased Malthus as arguing that 'since it is precisely the poor who are the surplus, nothing should be done for them except to make their dying of starvation as easy as possible, and to convince them that it cannot be helped and that there is no other salvation for their whole class than keeping propagation down to the absolute minimum, 49 while Marx noted sardonically in the Economic and Philosophic Manuscripts that the theory of population of the political economists was that there were 'too many people'. ${ }^{50}$

This is the background to Marx's observation, on the reproduction of the working class, that 'the capitalist may safely leave this to the worker's drives for self-preservation and propagation.'51 This remark has generally been snatched out of context, with some commentators claiming that it essentialises women and treats biological reproduction as 'natural' and eternal, rather than 'social', and socially constructed. ${ }^{52}$ It should by now be clear that there is no basis for this interpretation, first because, as we have seen, Marx regarded biological reproduction between humans as a social act, and second because this statement reflected a central tenet of his analysis of capitalist reproduction - that the process of capitalist development continually produces a surplus of available workers.

This intrinsic tendency for capitalist production to generate a constant surplus of available workers arises from the fact that the working population 'produces both the accumulation of capital and the means by which it is itself made relatively superfluous. ${ }^{53}$ As Gimenez pointed out in a brilliant analysis of the relationship between capitalism and population first published in 1977, for Marx the fact that capital, under conditions of competition, continually seeks to replace human labour with machines in search of greater productivity means that it constantly reproduces its own 'reserve army of labour', with the result that 'capital accumulation is indifferent to and independent from rates of population growth': 'The demand for labour is not identical with increase of capital, nor supply of labour with increase of the working class.... That the

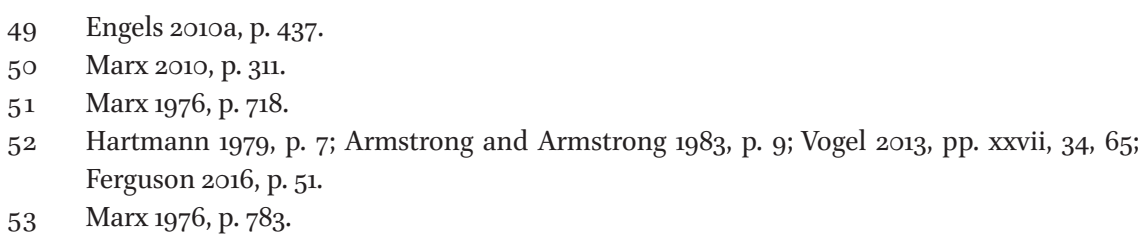


natural increase of the number of workers does not satisfy the requirements of the accumulation of capital, and yet, at the same time, exceeds those requirements, is a contradiction inherent in capital's very movement'.54

It follows that "population will always be "excessive" in relationship to the demand for labour, whatever its rate of growth may be. ${ }^{55}$ And while the advance of capitalist accumulation creates surplus labour, its periodic crises have the same consequence: 'Each crisis of accumulation increases the population of the unemployed and the unemployable by expelling from the work force sometimes forever - millions of workers and their families'.56 Overall, then, 'as the productivity of labour grows, the demand for labour declines, and an evergrowing mass of surplus population is generated, ${ }^{57}$ in a process specific to the capitalist mode of production.

It should be evident, then, that Marx's insistence that the individual capitalist could safely leave the maintenance and reproduction of the working class to the worker's drives for self-preservation and propagation does not reflect any form of essentialism, but rather stems first from the conditions of 'primitive accumulation', in which there is an apparently infinite supply of labour, and second from the contradiction inherent in the movement of capital itself, that it displaces labour as rapidly as it absorbs it.

\section{The Family in the History of Production and Exchange - I}

Marx was not blind to issues of gender. Nor was he so narrowly focused on industrial production that he ignored or neglected the family, the household, or what has been termed the 'private sphere'. As noted above, his intuition was that these aspects of social life would be shaped by the tendency of capital to 'subjugate every moment of production itself to exchange and to suspend the production of direct use-values not entering into exchange, i.e. precisely to posit production based on capital in place of earlier modes of production, which appear primitive from its standpoint. ${ }^{38}$ In particular, he was acutely attentive to the changing division of labour in industry, and its impact upon families and households, especially among the proletariat. At the same time, again as noted above, the main driver of advances in forms of production, the

\footnotetext{
54 Gimenez 2019, p. 134, citing Marx 1976, pp. 793, 794-5.

55 Ibid.

$56 \quad$ Gimenez 2019, p. 247.

57 Gimenez 2019, p. 293.

$58 \quad$ Marx 1973, p. 408.
} 
enlisting of science and technology to increase productivity in conditions of competition in large-scale industry, had little direct impact in his day on the household and domestic production, and none on human procreation. What he had to say, then, reflected these circumstances.

First, and contrary to some suggestions, ${ }^{59}$ Marx was thoroughly familiar with the use of female and child labour in industry, and assiduous from the start in exploring and documenting the extent of its empirical occurrence. In the Economic and Philosophic Manuscripts he transcribed lengthy sections on the employment of women and children from Wilhelm Schulz's Die Bewegung der Produktion, published only a year earlier in Switzerland, detailing the preponderance of female workers in English and American mills; and he noted, from Eugène Buret's De la misère des classes laborieuses en Angleterre et en France, first published in 1840, that the large workshops 'prefer to buy the labour of women and children, because this costs less than that of men'.60 Engels drew on direct observation of conditions in Manchester in the mid-1840s to note that the employment of women 'at once breaks up the family; for when the wife spends twelve or thirteen hours every day in the mill, and the husband works the same length of time there or elsewhere, what becomes of the children? They grow up like weeds; they are put out to nurse for a shilling or eighteenpence a week, and how they are treated may be imagined. ${ }^{61} \mathrm{He}$ did describe the situation, 'frequent in Manchester' with adult male unemployment rising, in which 'the wife supports the family, the husband sits at home, tends the children, sweeps the room and cooks' as one in which the world was 'turned upside down' - and in the German editions of 1845 and 1892 as 'virtual castration'.62 But he added that 'If the reign of the wife over the husband, as inevitably brought about by the factory system, is inhuman, the pristine rule of the husband over the wife must have been inhuman too'.63

These empirical observations register changes in the family and household in relation to the history of industry and exchange. The same focus recurs in Capital. Here Marx used the reports of factory inspectors and other official documents up to the 186os (by which time the scale of mechanisation under steam-power in textile factories in particular had advanced considerably) to document at length the extent of female and child labour, ${ }^{64}$ suggesting that the entry of women and children into the labour force was 'the first result of

59 Armstrong and Armstrong 1983, p. 11; Tepe-Belfrage and Steans 2016, p. 310.

6o Marx 2010, pp. 243, 245 .

61 Engels 2010b, p. 436.

62 Engels 201ob, p. 38, and footnote a.

63 Engels 2010b, p. 439.

64 Marx 1976, pp. 517-26, 574-5, 588-639. 
the capitalist application of machinery!' 65 In one specific example, he noted that the leading Birmingham steel-pen factory employed 1,268 female workers from five years' old upwards among its workforce of 1,428 in $1861 .{ }^{66}$ Not only that, but he also identified the pressure this development placed on the reproduction of labour-power and the sustenance of new life, in terms that identified the commodification of forms of provisioning previously carried out within the household, and what has since been called 'depletion, ${ }^{67}$ noting 'how capital, for the purposes of its self-valorization, has usurped the family labour needed for consumption':68

Since certain family functions, such as nursing and suckling children, cannot be entirely suppressed, the mothers who have been confiscated by capital must try substitutes of some sort. Domestic work, such as sewing and mending, must be replaced by the purchase of ready-made articles. Hence the diminished expenditure of labour in the house is accompanied by an increased expenditure of money outside. The cost of production of the working class family therefore increases, and balances its greater income. In addition to this, economy and judgement in the consumption and preparation of the means of subsistence becomes impossible. ${ }^{69}$

Again, citing a report from a Dr Edward Smith, sent by the British government to Lancashire, Cheshire and other places to investigate the state of health of cotton operatives during the crisis caused by the American Civil War (1861-5):

He reported that from a hygienic point of view, and apart from the banishment of the operatives from the factory atmosphere, the crisis had several advantages. The women now had sufficient leisure to give their infants the breast, instead of poisoning them with 'Godfrey's Cordial' (an opiate). They also had the time to learn to cook. Unfortunately, the acquisition of this art occurred at a time when they had nothing to cook.... This crisis was also utilized to teach sewing to the daughters of the workers in sewing schools. An American revolution and a universal crisis were

$65 \quad$ Marx 1976, p. 517.

$66 \quad$ Marx 1976, p. 59o, and footnote 71.

67 Rai, Hoskyns and Thomas 2014.

68 Marx 1976, p. 518 , footnote 38.

$69 \quad$ Marx 1976, p. 518, footnote 39 . 
needed in order that working girls, who spin for the whole world, might learn to sew!70

These were not casual references. They identify the household initially as a site of production in which a gendered division of labour assigns to women tasks directly associated with the reproduction of labour-power from day to day and generation to generation. Along with such responsibilities as cooking, they address handicraft production - sewing and mending - and the nursing of children. They then note the social and economic impact of the introduction of women to factory work - the 'reversal of roles' that makes husbands responsible for housework, or, where both partners work for a wage, the commending of infants to the 'care' of wet nurses who dosed them with opiates to induce quietness; the process of commodification arising from the purchase of goods formerly produced in the home; and the destabilising cycle arising from periodic crises. Elsewhere, Marx notes the negative overall impact on wages of the introduction of steam-driven machinery on a massive scale in one branch of industry, with the consequent laying-off of thousands of hands making workers cheaper and more abundant elsewhere, leading many capitalists to opt for cheaper labour rather than costly investment in machines. He documents roving agricultural labour gangs of married women, boys and girls, and public markets at Bethnal Green for the short-term hiring-out of children from 9 years of age upwards to silk manufacturers ('1s. 8d. a week (this belongs to the parents) and "2d. for myself and tea"'), ${ }^{71}$ and records that there were more domestic servants $(1,208,648$, of whom nearly 90 per cent were female) than workers in textile factories and metal industries combined. ${ }^{72}$ Again, he notes the initial reluctance of Parliament to interfere with parental authority, and its eventual acknowledgement that 'large-scale industry, in overturning the economic foundation of the old family system, and the family labour corresponding to it, had also dissolved the old family relationships', quoting from the 1866 report of the Children's Employment Commission ('It is, unhappily, to a painful degree apparent throughout the whole of the evidence, that against no persons do the children of both sexes so much require protection as against their parents'); and he comments that it was not 'the misuse of parental authority that created the direct or indirect exploitation of immature labour-powers by capital, but, rather the opposite, i.e. the capitalistic mode of exploitation, by sweeping away the economic foundation which corresponded to parental

\footnotetext{
$70 \quad$ Marx 1976, p. 518 , footnote $3^{8}$.

71 Marx 1976, p. 520.

72 Marx 1976, pp. 574-5.
} 
power, made the use of parental power into its misuse. ${ }^{73}$ Marx was attentive, then, to the impact of industrial capitalism on the household, in terms of both the gendered division of labour and the reproduction of labour-power from day to day. And throughout, his analysis reflected the observation that where the bourgeois mode of production predominates over the rest, its relations assign rank and influence to others.

I turn now to the history of the family and household in relation to production and exchange since Marx's day. Not only in principle, but also now in practice, it turns out that every task carried out in the 'domestic sphere' - from the production of food to that of future generations - is susceptible to commodification, and if individual capitalist concerns can generate surplus-value from it, they will seek to do so as the technical means become available. Scientific and technological revolution since Marx's day has given rise, especially over recent decades, to whole new branches of theory and practice - notably in computing, large data processing, logistics, nanotechnology, robotics and biotechnology - which were either in their infancy or unheard-of in those times. This has in turn enabled multiple connected revolutions in production, trade and finance, creating new products and markets, and cutting the time and cost of producing goods and bringing them to market. Urban consumers and once remote and isolated rural producers are linked to markets by mobile technology and speeded-up systems of delivery, while innovations in robotisation and artificial intelligence have brought about specific developments such as sensor-driven fruit picking machines and self-driving vehicles, which confirm the acuity of Marx's insight into the tendency for techniques of machine production to advance without regard for the capacity of the human hand. The most advanced forms of production today literally take no account of the capacity of the human hand, eye, or brain, but instead exploit the capacity of the machine to overcome the limits of human physiology, and perform new processes accurately and tirelessly. The impact upon the family and household has been precisely as Marx's analytical framework supposed.

First, it is evident, just as in Marx's day, that capital observes no limits in its quest to secure direct access to labour-power, and digital platforms in particular have enabled the fragmentation of labour and intensified competition for work. Second, and related, the 'standard employment contract', featuring 
full-time employment with a degree of stability and with attendant social benefits, is itself facing extinction. Third, the dramatic increase, absolute and relative, of female participation in the labour market has done away entirely with the notion of the male breadwinner as the norm. Fourth, concomitant changes have taken place in the composition of families and households and in choices regarding childbearing, so that in the advanced economies the 'nuclear family' is nowhere any longer the norm, and in the developing world households increasingly depend upon exporting labour, often to provide care-related services to the former. Fifth, at the same time, experience continues to show to the capitalist a constant excess of population - the issue being not the scarcity of available bodies around the world, but the quest to convert the huge surplus into wage labourers. Sixth, the period since Marx's day has seen the appearance of a range of domestic or household appliances, initially powered by gas or electricity, and more recently embracing digital and internet-based technologies, while their transformative effect has been limited by the primitive conditions of domestic production. Seventh, the replacement of 'handicraft' production within the home by labour, goods and services purchased in the market has expanded out of all recognition, with care for children or the elderly and the purchase of prepared or cooked meals the most prominent examples. And eighth, the production of life itself has been seized by capital, following precisely the pattern of breaking the process of production down into its smallest constituent parts, and replacing the 'petrified forms' of the previously existing social-production process with 'conscious and planned applications of natural science, divided up systematically in accordance with the particular useful effect aimed at in each case'. So in this final section I consider each of these developments briefly in turn.

First, then, precisely along lines that Marx suggested, an intensified division of labour has been enabled by recent technological advances. We are now more than half a century into the global pattern of fragmentation of production, which opens up the whole world as a site for the extraction of value, with individual products routinely assembled over numerous national jurisdictions. More recently, as the digital revolution has advanced, the capacity of capital to seize upon fragments of available labour-power literally anywhere in the world has increased beyond all recognition as out-sourcing, freelancing, 'flexible working', and 'zero-hours contracts' have proliferated. Digital platforms such as Mechanical Turk, MyLittleJob, PeoplePerHour, Taskrabbit and Upwork, or Comatch, Worksome and Outsized, match workers to tasks which may be the tiniest constituent elements of larger production processes, and do so on a global scale for skilled professional and unskilled work alike. Whatever fragment of the labour-power of an individual is available can be targeted and 
seized upon by capital. In the UK, the dramatic rise in zero-hours contracts from around 200,000 in 2012 to over 900,00o five years later, alongside only slightly lower numbers of agency workers, has greatly increased the heterogeneity and 'flexibility' of the workforce. ${ }^{74}$ These workers, importantly, are not to be equated to the unskilled and marginalised individuals on the periphery of capitalist production in its period of emergence. Rather, consistently with Marx's expectations, they need the flexibility, the varied skills and above all the willingness (induced by the discipline of labour-market competition and the narrowing down of alternative sources of survival) to serve capital in its most advanced organisational forms, at the lowest possible cost. So these patterns of employment are not a throwback to the past, but a measure of the extent to which capitalism has outgrown the unstable and inevitably temporary class compromise that briefly prevailed in a few advanced economies in a short period of the late twentieth century.

Second, these developments increase the flexibility of labour to a point where the 'standard employment contract', with its attendant rigidity and ancillary costs from the perspective of capital, is becoming a thing of the past. In a single generation, punitive legislation over labour organisation and contracts has all but done away with it. ${ }^{75}$ The trend today is towards short-term and parttime contracts, outside the scope of labour law, and every benefit won through struggle by workers without rights is at the same time another step towards the establishment of a new model contract which makes 'totally developed individuals' available for whatever work is required of them at any time. ${ }^{76}$

Third, it is now forty years since Heidi Hartmann suggested that " $\mathrm{t}] \mathrm{he}$ "ideal" of the family wage - that a man can earn enough to support an entire family - may be giving way to a new ideal that both men and women contribute through wage earning to the cash income of the family'.77 So the demise of the 'male breadwinner' (always something of an ideological construct as far as working-class families were concerned) is nothing new. However, the combined effects of the 'reform' (that is, reversal) of welfare, and austerity politics, over recent decades have done away with it entirely. The July 2018 bulletin on the UK labour market from the Office for National Statistics recorded that at the end of May 2018 the employment rate (the proportion of people aged from 16 to 64 years who are in work) was 75.7 per cent, up by o.8 per cent from the

74 D'Arcy 2017; Judge and Tomlinson 2016.

75 Adams, Freedland and Prassl 2014; Bruun, Lörcher and Schömann (eds.) 2014; Freedland 2016.

76 Freedland 2019.

77 Hartmann 1979, p. 19. 
previous year, and the highest since comparable records began in 1971. While the proportion for men was 80.1 per cent, a point last reached in 1991, that for women, at 71.3 per cent, was also the highest since records began, in part because of the rise in the pensionable age for women from 60 to 65 ; and 58.8 per cent of female employees were in full-time work, while 642,00o (a further 4.2 per cent) were working two jobs. ${ }^{78}$ Policies of austerity and competition for jobs have meanwhile held down wages, which remained in real terms the same as they were in 2006 (after peaking early in 2008 and declining thereafter before beginning a glacially slow recovery). The previous conjuncture of expanding welfare, the 'male breadwinner norm' and relative prosperity was a local, temporary, anomalous and unsustainable aspect of capitalist development at an early, incomplete stage, and is now long gone. Across the wider developed world, and in the EU in particular, a policy frame of 'social investment' - in which the focus is on 'how to support women to enter and remain in the labour market', and the citizen envisaged is 'first and foremost a paid worker, either in actuality or (when a child) in the making' - reflects the same determination that everyone should depend upon a wage. ${ }^{79}$ In the UK again, the pensionable age for men and women alike is set to rise in stages to 68 by 2039, and it would be rash to assume that we are not on the verge of a 'world without retirement'. ${ }^{80}$ In short, circumstances are more conducive than ever to making every worker a wage labourer for capital.

Fourth, changes have taken place in the composition of families and households and choices regarding childbearing, under the pressure of the advancing demands of commodification and welfare reform. Already a decade ago there were more households in the UK with a single adult worker ( 2 o per cent) than with two (or more) adults and only one worker (17 per cent), and 47 per cent of households had two or more workers. ${ }^{81}$ And in 2018, only $3^{2}$ per cent of families and 22 per cent of households consisted of a married or cohabiting couple with a dependent child or children - the traditional 'nuclear family'; lone parents made up a further 9.5 per cent of families; and 44 per cent of the minority of 'nuclear families' had a single child. Partly as a consequence of increased longevity, 29 per cent of households consisted of a single person..$^{82}$ As this reflects, there has been a transformation in the pattern of human reproduction: in 1971 (England and Wales only), 'women in the 20 to 24 age category were the

\footnotetext{
78 ONS 2018b, pp. 2, 8, and Appendix, Table 3.

79 Saraceno 2015 , p. 257.

8 o Hill 2017.

81 Brewer and Wren-Lewis 2011, p. 7.

82 ONS 2019, pp. 1-3.
} 
largest group giving birth, accounting for 36.5 per cent of all live births. By 2010 this proportion had fallen to 19 per cent, and the 30-34 age category, whose proportion had doubled to 28 per cent between 1971 and 2010, accounted for more live births than any other group' The share of live births to women of 35 and over rose from 7.4 to 19.8 per cent. ${ }^{83}$ This process of change has continued. Only a quarter of women who reached age 25 in 2017 had at least one child the lowest percentage on record, while for those who reached 45 , the average completed family size was 1.89 children - the smallest since records began in 1920. The significant features behind this figure were the increasing tendency to delay childbearing, and the growing percentage of women with no children: 'For women born in 1945, 18\% were childless at exact age 30 years. For women born in the 1970s onwards, this figure was just under 50\%'; and nearly one in five women born in 1972 was childless by age 45, compared to under one in ten for those born in $1946 .{ }^{84}$ And as is increasingly recognised, this development is echoed in dramatically falling fertility rates around the world, with only a few countries in West Africa standing outside what is otherwise a global trend.

Fifth, however, it is strikingly the case that despite this, there are hundreds of millions of individuals around the world, situated in the low-investment, low-productivity 'informal' sector, who are potentially available for recruitment and exploitation by capital. The ILO estimates that there were 172 million people unemployed worldwide in 2018 , along with a further 140 million 'who are looking for a job but are not able to take up employment, or who are available but are not looking for a job. ${ }^{85}$ Beyond that, the organisation identifies some 360 million 'contributing family workers who lack effective access to social protection and income security', an additional 1.1 billion working on their own account, with a large proportion engaged in 'subsistence activities that are pursued because of the absence of job opportunities in the formal sector or the lack of a social protection system', meaning that 'just over half ( $5^{2}$ per cent) of global workers are wage and salaried employees', with 40 per cent of such jobs themselves classified as informal: 'Overall,' it concludes, 'a staggering 2 billion workers are in informal employment, accounting for three in five (61 per cent) of the world's workforce'. ${ }^{86}$ Meanwhile, the World Bank and the oECD, leading voices on behalf of global capital, express no concern at all about falling global birth-rates. On the contrary, they are currently mounting a global campaign against informal labour in the name of 'more and better jobs' - jobs, in

\footnotetext{
83 ONS 2012, pp. 2, 21.

84 ONS $2018 \mathrm{a}, \mathrm{p} .5$.

85 ILO 2O19, p. 2.

86 ILO 2O19, p. 6.
} 
other words, in which healthy, skilled and flexible workers are available to and exploitable by capital. ${ }^{87}$ Capital, in short, worries itself no more today about procreation than it ever did, as experience continues to show it a constant excess of population. To all intents and purposes, it shares Shulamith Firestone's insistence that 'women have no special reproductive obligation to the species'. ${ }^{8}$

Sixth, the period since Marx's day has seen the increased application of science and technology to the home, with the appearance of a range of domestic or household appliances powered by gas or electricity, and more recently embracing digital and internet-based technologies. The first electric lights date from around the time of Marx's death, though their use in domestic settings was slow to develop, and initially, as with many other subsequent developments, confined to wealthy households. Over the intervening years, refrigerators, electric ovens and toasters, vacuum cleaners, washing machines, dishwashers and the like have become commonplace. In the current wave of technological advance, the 'smart' home and the 'Internet of Things' exploit the potential of miniaturisation, automatic sensors and connectivity, while domestic robots loom over the horizon. ${ }^{89}$ Whether or not such devices reduce the time devoted to housework is not the point: ${ }^{90}$ for the most part, the underlying logic is still that of handicraft in a small unit, with limited division of labour and a process of production that is aided by the machine but not otherwise transformed. In other words, the tendency for household appliances not to save labour time is a consequence of the relative inefficiency of household production.

Seventh, as the character of households changes, and more women enter the labour force on a long-term and full time or quasi-full time basis, more labour, goods and services are procured outside the home. Again, the trend is not new. Fifty years ago, Benston noted that day care was available, 'even if inadequate and perhaps expensive; convenience foods, home delivery of meals and take-out meals are widespread; laundries and cleaners offer bulk rates. ${ }^{91}$ Dual-wage families in wealthy countries now increasingly outsource care and domestic labour to poor women and particularly legal and illegal migrants, ${ }^{92}$ and such choices are encouraged by the trend to subordinate family policy in developed economies to the demands of the labour market, and by immigration law reform..$^{93}$ At the same time, production in the home of the necessi-

\footnotetext{
87 World Bank 2012; World Bank 2018; OECD 2019.

88 Firestone 1970, p. 233.

89 Schroeder 1986; Chin, Callaghan and Ben Allouch 2019.

$90 \quad$ Benston 2019, p. 22.

91 Benston 2019, pp. 8-9.

92 Estévez-Abe 2015; Leerkes 2016; Arat-Koç 2018.

93 Ferragina and Seeleib-Kaiser 2015; Fudge 2018.
} 
ties for the daily renewal of labour-power is increasingly replaced by supply from outside, bringing about major shifts in domestic work and provisioning. The 'typical' family of four or five with a male breadwinner, full-time female housewife and two or three children, enjoying home-cooked meals prepared from scratch, may offer only a very approximate guide to past reality, but now this stereotype is completely invalid. Yates and Warde write of the 'de-structuration of the meal', with an indicative 2012 UK survey suggesting a rise in companionless eating, with around a third of all meals eaten alone, and less than a quarter of them requiring cooking or complex preparation. ${ }^{94} \mathrm{~A}$ revolution in food processing and hence provisioning has taken place since the $1980 \mathrm{os}$. 'Acceleration in food science techniques', Monteiro and colleagues report, 'has enabled invention of a vast range of palatable [ sic] products made from cheap ingredients and additives', with the consequence that 'enterprises whose profits derive from uniformly branded ready-to-consume products have become colossal global corporations. ${ }^{95}$ The most dynamic growth today, driven by competition between Western transnationals and emerging local corporations, is in Asia, which is in the grip of a 'nutrition transition' of which carbonated soft drinks supplied by a global market are the leading edge. ${ }^{96}$ At the same time, as sandwiches increasingly replace cooked meals, sandwich-making has been captured by transnational capital. Greencore, founded in Ireland in 1991 upon the privatisation of Irish Sugar, produces 1.5 billion sandwiches and other related food-to-go products per year. ${ }^{97}$ And a new revolution in prepared-meal provision is gathering pace, as mobile and web-based platforms such as Just Eat and Deliveroo combine advanced networks and logistics with zero-hours workers and industrial kitchens to expand options for the purchase and home delivery of 'restaurant' meals. In turn, the rapidly growing market for commercially prepared food is an artefact of the social changes identified above - so much so that telephone/take-away and microwave/ready-meal combinations are replacing cooked meals prepared from scratch across new and old forms of household alike.

Eighth and finally, the process of the production of life itself is being transformed by 'conscious and planned applications of natural science', and seized by capital, confirming the validity of the expectation that the production of life, in all its aspects, has to be approached, in principle, in relation to an emerging bourgeois mode of production, with its incessant division of labour, constant

94 Yates and Warde 2017, pp. 98, 102, 106.

95 Monteiro, Moubarac, Cannon, Ng and Popkin 2013, p. 22.

$96 \quad$ Baker and Friel 2016, p. 26.

97 Financial Times 2016. 
technological revolution, universal competition, and the subordination of the natural sciences to capital. Such changes have occurred with extreme rapidity since the first successful in vitro fertilisation (IVF) at Oldham's Centre for Human Reproduction in 1978, following various lines. First, 'new' or assisted reproductive technologies (NRT s, ART s) have given rise to a global industry. ${ }^{98}$ Second, efforts to create an artificial environment in which a fertilised egg can be gestated and brought to maturity, the so-called 'artificial womb', are said to be in the offing. ${ }^{99}$ Third, at the end of November 2018 the first 'gene-edited' babies were reported - created in China by a scientist trained at Stanford University. ${ }^{100}$ At the same time, the appearance of 'contract pregnancy' or the 'commodified womb' are significant aspects of the commodification of the human body, ${ }^{101}$ a trend which is just as evident in markets for organs, tissues, blood and stem-cells, and in the use of human subjects for large-scale drug trials. ${ }^{102}$ When Armstrong and Armstrong argued nearly forty years ago that the 'separation under capitalism between commodity production and human reproduction (including the reproduction of the commodity labour power) in turn implies a particular division of labour between the sexes, and thus a division within classes', and that 'babies can be produced only by fertile women', they unwittingly fell short of their ambition to produce 'an analysis of biology that is historical, materialist and dialectical. ${ }^{103}$ It is now clear, as it could only be in abstract prospect in Marx's time, that the historical-materialist framework does indeed encompass production in capitalist society in all its forms, including 'the production of life, both of one's own in labour and of fresh life in procreation'.

\section{Conclusion}

Marx treats 'societal reproduction' not separately but simply as the outcome of a single, complex and historically-evolving totality, governed by the logic of competition between capitals, and the dependence of the dispossessed on wage labour, and rightly so. To distinguish 'social reproduction' from 'production', or to separate it out from the social production process as a whole, is to construe as fixed boundaries that are fluid, and to single out as exceptional

\footnotetext{
$98 \quad$ Pelzman 2013.

99 Bulletti, Palagiano, Pace, Cerni, Borini and de Ziegler 2011; Devlin 2017.

100 Ahuja, Liu and Lucas 2018.

101 Bailey 2011; Hewitson 2014.

102 Rainhorn and El Boudamoussi (eds.) 2015; Sunder Rajan 2017.

103 Armstrong and Armstrong 1983, pp. 8, 9, 28.
} 
what are fundamental and constitutive aspects of the social production process, subject to transformation over time through a 'constant flux of renewal' in which all other forms of production are ranked, influenced, and subject to being taken over by capital. So when writers on 'social reproduction' go beyond its definition as 'the activities associated with the maintenance and reproduction of peoples' lives on a daily and intergenerational basis,', ${ }^{104}$ whether to include such concepts as 'affect' and 'care', or to insist that capital requires a particular role for women and the household or family, they produce too rigid a concept. These relations change over time, in accordance with the shaping of the history of humanity by industry and exchange. What is more, capital does not 'care'. Hence the 'permanent crisis of reproduction caused by the indifference of capital to the physical and social reproduction of the workforce.'.05 Capital does not respect the 'need' for a 'separate sphere' of social reproduction, or the replenishment of labour-power, any more than it respects the life of the individual worker or worries itself about future generations. So while Laslett and Brenner were right to insist that an analysis of societal reproduction requires direct attention to the division of labour by gender, they were mistaken to think either that in the development of capitalism gender relations are 'perpetuated' in any specific form, or that Marx's concept of societal reproduction is insufficient to the task. ${ }^{106}$ At the same time, the fact that gender relations across all forms of production and relations between households and the global capitalist economy are fundamental constituent parts of the rich totality of relations and determinations that shapes trajectories of change makes their study central to historical materialism, especially at the present time. Such study takes us to the heart of the specific manner in which capital is currently seeking to 'subjugate every moment of production itself to exchange and to suspend the production of direct use values not entering into exchange.' ${ }^{107}$ The argument advanced here is that Marx does, after all, provide the best starting point.

\section{References}

Adams, Abi, Mark Freedland and Jeremias Prassl 2015, "The "Zero-Hours Contract": Regulating Casual Work, or Legitimating Precarity?', Oxford Legal Studies Research Paper No ${ }^{11} / 2015$.

\footnotetext{
104 Ferguson, LeBaron, Dimitrakaki and Farris 2016, pp. 27-8.

105 Gimenez 2019, p. 300.

106 Laslett and Brenner 1989, p. 383.

107 Marx 1973, p. 408.
} 
Ahuja, Anjana, Nicolle Liu and Louise Lucas 2018, 'Mastering Evolution: The World's First Gene-Edited Babies', Financial Times, 30 November, available at: <https:// www.ft.com/content/126689a4-f48e-11e8-9623-d7f9881e729f>.

Arat-Koç, Sedef 2018, 'Migrant and Domestic and Care Workers: Unfree Labour, Crises of Social Reproduction and the Unsustainability of Life under "Vagabond Capitalism", in Handbook on the International Political Economy of Gender, edited by Juanita Elias and Adrienne Roberts, pp. 411-26, Cheltenham: Edward Elgar.

Armstrong, Pat and Hugh Armstrong 1983, 'Beyond Sexless Class and Classless Sex: Towards Feminist Marxism', Studies in Political Economy, 10, 1: 7-43.

Bailey, Alison 2011, 'Reconceiving Surrogacy: Toward a Reproductive Justice Account of Indian Surrogacy', Hypatia, 26, 4: 715-41.

Baker, Philip and Sharon Friel 2016, 'Food Systems Transformations, Ultra-processed Food Markets and the Nutrition Transition in Asia', Globalization and Health, 12, 80, $<$ DOI:10.1186/s12992-016-0223-3>.

Benston, Margaret 2019 [1969], 'The Political Economy of Women's Liberation', Monthly Review, 71, 4, <DOI:10.14452/MR-071-04-2019-08_1>.

Bhattacharya, Tithi (ed.) 2017, Social Reproduction Theory: Remapping Class, Recentering Oppression, London: Pluto Press.

Bonefeld, Werner 2014, Critical Theory and the Critique of Political Economy: On Subversion and Negative Reason, London: Bloomsbury.

Brewer, Mike and Liam Wren-Lewis 2011, 'Why Did Britain's Households Get Richer? Decomposing UK Household Income Growth between 1968 and 2008-o9', Institute for Social and Economic Research, ISER Working Paper Series 2012-o8, available at: <https://www.resolutionfoundation.org/app/uploads/2014/o8/Why-did -Britains-households-get-richer.pdf>.

Bruun, Niklas, Klaus Lörcher and Isabelle Schömann (eds.) 2014, The Economic and Financial Crisis and Collective Labour Law in Europe, Oxford: Hart Publishing.

Bulletti, Carlo, Antonio Palagiano, Maria Caterina Pace, Angelica Cerni, Andrea Borini and Dominique de Ziegler 2011, 'The Artificial Womb', Annals of the New York Academy of Sciences, 1221, 1: 124-8.

Cammack, Paul 2016, Review of Social Reproduction by Antonella Picchio, What's Worth Reading, available at: <https://whatsworthreading.weebly.com/social-repro duction.html>.

Chin, Jeannette, Vic Callaghan and Somaya Ben Allouch 2019, 'The Internet-of-Things: Reflections on the Past, Present and Future from a User-centered and Smart Environment Perspective', Journal of Ambient Intelligence and Smart Environments, 11, 1: $45^{-69}$.

D’Arcy, Conor 2017, 'Workers on Zero Hours Contracts Hits a Record High - But Have they Reached their Peak?', Resolution Foundation, 3 March, available at: <https:// www.resolutionfoundation.org/comment/workers-on-zero-hours-contracts-hits-a -record-high-but-have-they-reached-their-peak/>. 
Devlin, Hannah 2017, 'Artifical Womb for Premature Babies Successful in Animal Trials', The Guardian, 25 April, available at: <https://www.theguardian.com/ science/2017/apr/25/artificial-womb-for-premature-babies-successful-in-animal -trials-biobag>.

Engels, Friedrich 2010a, 'Outlines of a Critique of Political Economy', in Marx/Engels Collected Works, Volume 3, pp. 418-43, London: Lawrence and Wishart.

Engels, Friedrich 2010b, 'The Condition of the Working-Class in England', in Marx/ Engels Collected Works, Volume 4, pp. 295-596, London: Lawrence and Wishart.

Estévez-Abe, Margarita 2015, 'The Outsourcing of House Cleaning and Low Skill Immigrant Workers', Social Politics, 22, 2: 133-46.

Ferguson, Sue 1999, 'Building on the Strengths of the Socialist Feminist Tradition', Critical Sociology, 25, 1: 1-15.

Ferguson, Susan 2016, 'Intersectionality and Social-Reproduction Feminisms: Toward an Integrative Ontology', Historical Materialism, 24, 2: 38-6o.

Ferguson, Susan, Genevieve LeBaron, Angela Dimitrakaki and Sara B. Farris 2016, 'Introduction', Historical Materialism, 24, 2: 25-37.

Ferguson, Susan and David McNally 2013, 'Capital, Labour-Power, and GenderRelations: Introduction to the Historical Materialism Edition of Marxism and the Oppression of Women', in Vogel 2013, pp. xvii-xl.

Ferragina, Emanuele and Martin Seeleib-Kaiser 2015, 'Determinants of a Silent (R)evolution: Understanding the Expansion of Family Policy in Rich OECD Countries', Social Politics, 22, 1: 1-37.

Financial Times 2016, 'Greencore to Acquire US Group Peacock Foods for $\$ 748 \mathrm{~m}$, 14 November, available at: <https://www.ft.com/content/f643624e-aa41-11e6-aobb $-97 \mathrm{f}_{42} 551 \mathrm{dbf} 4>$.

Firestone, Shulamith 1970, The Dialectic of Sex: The Case for Feminist Revolution, New York: William Morrow and Co.

Freedland, Mark 2016, 'The Contract of Employment and the Paradoxes of Precarity', Oxford Legal Studies Research Paper No 37/2016.

Freedland, Mark 2019, 'New Trade Union Strategies for New Forms of Employment A Brief Analytical and Normative Foreword', European Labour Law Journal, 10, 3: 179-82.

Fudge, Judy 2018, 'Illegal Working, Migrants and Labour Exploitation in the UK', Oxford Journal of Legal Studies, 38, 3: 557-84.

Gimenez, Martha E. 2019, Marx, Women, and Capitalist Social Reproduction: Marxist Feminist Essays, Historical Materialism Book Series, Leiden: Brill.

Hartmann, Heidi L. 1979, 'The Unhappy Marriage of Marxism and Feminism: Towards a More Progressive Union', Capital \& Class, 8, 1: 1-33.

Hewitson, Gillian 2014, 'The Commodified Womb and Neoliberal Families', Review of Radical Political Economics, 46, 4: 489-95. 
Hill, Amelia 2017, 'A World Without Retirement', The Guardian, 29 March, available at: <https://www.theguardian.com/membership/2017/mar/29/a-world-without -retirement>.

Historical Materialism 2016, Symposium on Social Reproduction, Volume 24, Issue 2. ILO 2019, World Employment Social Outlook: Trends 2019, Geneva: International Labour Organization.

Judge, Lindsay and Daniel Tomlinson 2016, Secret Agents: Agency Workers in the New World of Work, London: The Resolution Foundation, available at: <https://www .resolutionfoundation.org/publications/secret-agents-agency-workers-in-the-new -world-of-work/>.

Laslett, Barbara and Johanna Brenner 1989, 'Gender and Social Reproduction: Historical Perspectives', Annual Review of Sociology, 15: 381-404.

Leerkes, Arjen 2016, 'Back to the Poorhouse? Social Protection and Social Control of Unauthorised Immigrants in the Shadow of the Welfare State', Journal of European Social Policy, 26, 2: 140-54.

Marx, Karl 1973 [1857-8/1939, 1953], Grundrisse: Foundations of the Critique of Political Economy, translated by Martin Nicolaus, Harmondsworth: Penguin.

Marx, Karl 1976 [1867], Capital: A Critique of Political Economy. Volume One, translated by Ben Fowkes, Harmondsworth: Penguin.

Marx, Karl 2010 [1844], 'Economic and Philosophic Manuscripts', in Marx/Engels Collected Works, Volume 3, pp. 229-346, London: Lawrence and Wishart.

Marx, Karl and Friedrich Engels 2010 [1845-6], The German Ideology, in Marx/Engels Collected Works, Volume 5, pp. 19-644, London: Lawrence and Wishart.

Monteiro, C.A., J.C. Moubarac, G. Cannon, S.W. Ng and B. Popkin 2013, 'Ultra-processed Products Are Becoming Dominant in the Global Food System', Obesity Review, 14, Supplement 2: 21-8.

Monthly Review 2019, Special Issue Honouring Margaret Benston, Volume 71, Issue 4. OECD 2019, OECD Employment Outlook 2019: The Future of Work, Paris: Organisation for Economic Co-operation and Development.

ONS 2012, Measuring National Well-being - Households and Families, 2012, Newport:

Office for National Statistics.

ONS 2018a, Childbearing for Women Born in Different Years, England and Wales: 2017,

Newport: Office for National Statistics.

ONS 2018b, UK Labour Market:July 2018, Newport: Office for National Statistics.

ONS 2019, Families and Households: 2018, Newport: Office for National Statistics.

Pelzman, Joseph 2013, “Womb for Rent": International Service Trade Employing Assisted Reproduction Technologies (ARTs)', Review of International Economics, 21, 3: 387-400.

Picchio, Antonella 1992, Social Reproduction: The Political Economy of the Labour Market, Cambridge: Cambridge University Press. 
Radical Philosophy 2019, 'Dossier: Social Reproduction Theory', II, 4.

Rai, Shirin M., Catherine Hoskyns and Dania Thomas 2014, 'Depletion', International Feminist Journal of Politics, 16, 1: 85-105.

Rainhorn, Daniel and Samira El Boudamoussi (eds.) 2015, New Cannibal Markets: Globalization and Commodification of the Human Body, Hermance: Fondation Brocher.

Rosenberg, Nathan 1974, 'Karl Marx on the Economic Role of Science', Journal of Political Economy, 82, 4: 713-28.

Saraceno, Chiara 2015, 'A Critical Look to the Social Investment Approach from a Gender Perspective', Social Politics, 22, 2: 257-69.

Schroeder, Fred E.H. 1986, 'More "Small Things Forgotten": Domestic Plugs and Receptacles, 1881-1931', Technology and Culture, 27, 3: 525-43.

Seccombe, Wally 1983, 'Marxism and Demography', New Left Review, I, 137: 22-47.

Sunder Rajan, Kaushik 2017, Pharmocracy: Value, Politics and Knowledge in Global Biomedicine, Durham, NC: Duke University Press.

Tepe-Belfrage, Daniela and Jill Steans 2016, 'The New Materialism: Re-claiming a Debate from a Feminist Perspective', Capital \& Class, 40, 2: 305-26.

Viewpoint Magazine 2015, Special Issue on Social Reproduction, Volume 5.

Vogel, Lise 2013 [1983], Marxism and the Oppression of Women: Toward a Unitary Theory, Historical Materialism Book Series, Leiden: Brill.

World Bank 2012, World Development Report 2013:Jobs, Washington D.C.: World Bank. World Bank 2018, World Development Report 2019: The Changing Nature of Work, Washington D.C.: World Bank.

Yates, Luke and Alan Warde 2017, 'Eating Together and Eating Alone: Meal Arrangements in British Households', British Journal of Sociology, 68, 1: 97-118. 